\title{
WOMB CONTROL IN TONI MORRISON'S BELOVED
}

\author{
Yuniar Fatmasari \\ English Education Study Program \\ Peradaban University \\ Email: yuniarefes@gmail.com
}

\begin{abstract}
This study reveals the ideological strategies the dominant takes to exploit Black enslaved women's womb experienced by the characters in Toni Morrison's Beloved as well as their resistance. Written in 1987, the novel is set eight years after the end of the Civil War in time painful experiences during slavery era are still there in the mind of ex-enslaved Black women and men. The novel narrates the past through personal life experiences presented by Sethe and Baby Suggs. During slavery era, their bodies are not merely used to work in the plantation area but since they are women, their wombs are valuable commodity providing advantages and profit to the masters. To make it possible, the dominant function ideological strategies to control the Black enslaved women's wombs. Therefore, this study tries to explore how the ideological strategies are practiced in the novel. According to Collins, creating negative images such as mammy, breeder woman, and jezebel addresses to the bodies of Black enslaved women belongs to ideological strategy which is more powerful compared to the economic and politic strategy. Each image covers dominant interest to control Black women's womb under new-progressive capitalism in United States. The result of the study shows that those three images works effectively to control the Black enslaved women, even nowadays, those images are still there in the body of young generation of Black women and provide another form of womb's control. However, the study as well finds out that the resistance toward the oppression is also varied. Self-definition is presumed to be a fundamental element to the journey of internalized oppression to the 'free mind' which eventually leads to the action of resistance. With this self-definition, Black women begin to deny the existed negative images controlling their wombs.
\end{abstract}

Keyword: image, womb control, mammy, breeder woman, jezebel, self-definition.

\section{Introduction}

Beloved is a novel written by AfricanAmerican writer Toni Morrison in 1987. She talks much on racial segregation, violence, and discrimination experienced by Black enslaved women in slavery era. Most of her ideology is delivered through stories of personal lives owned by the characters in the novel, especially Sethe and Baby Suggs. Sethe is a Black exenslaved woman who has to remember all things happened in the past including all devices controlling her womb. In time of slavery era, she remembered that she had to run away from Sweet Home to protect her children and the growing baby in her womb. Her escaping had never become a way out because she had to face another problem. The Fugitive Bill Act demands every escaped slave to be chased and arrested because they are still a legitimate belonging to their masters, including their children. Sethe tried to refuse this condition by conducting some effort of resistance, so did Baby Suggs. What happened in the past on behalf of severe slavery, according to Morrison, is part of American history which is mostly untold and unwritten in American history thus she tries to uncover. She believes that what happened in the past must have big contribution to what happens in the future, it has role in the construction of American society view toward Black women nowadays. It could answer the reason of the continued racial segregation, class and gender discrimination experienced by the new generation of AfricanAmerican women.

African-America women are those inheriting African, European, and American blood whose ancestors were brought to 


\section{Jurnal Poetika Vol. IV No. 1, Juli 2016}

America as slaves. Since slavery is eliminated in 1863, racial difference in fact keeps animating discrimination toward Black women's body nowadays. They still suffer economic, politic, and social inequality. This kind of segregation does not appear naturally, their ancestors' past as slave among $17^{\text {th }}$ to $18^{\text {th }}$ century eventually posits one of several reasons generating the discrimination. Not just because of their skin color, but also ideological oppression attached to their body during slavery era.

Collins (2004: 55) states that under chattel slavery, people of African descent occupied a particular place in class relation -their bodies and all that is contained in those bodies (labor, sexuality, and reproduction) are objectified and turn into commodities that are traded in the marketplace; especially Black women. In line with Collins, Omolode (1994: 7) explains that the owners of slaves define their slave women as commodity, eliminating their feeling and rights to choose; their head and heart are separated from their hands, and they are divided into womb and vagina.

With this kind of historical background, Black women suffer less favorable position in class relation even after slavery ends. The traces of objectification on the bodies remain exist in African-American's mind and automatically construct new social and dominant view on Black women's body nowadays. In slavery, Black women were workers like men; they did hard manual labor. But because they were women, their sexuality and reproductive capacity provide opportunities for forms of sexual exploitation and sexual slavery -ultimate submission of the master/slave relationship (Collins, 2004: 55).

Black enslaved women bodies are the most objectified institution compared to Black enslaved men. Their wombs are exploited; their right on reproduction is dismissed and substituted with policies created by the dominant -their masters. Womb is well-known as the most sacred part of women's body to create new generation as well as continuation of human civilization. Womb (Tim Taylor, 2016) is called as uterus means a hollow muscular organ of the female reproductive system that is responsible for the development of the embryo and fetus during pregnancy. An incredibly distensible organ, the uterus can expand during pregnancy from around the size of a closed fist to become large enough to hold a full term baby. It is also an incredibly strong organ, able to contract forcefully to propel a full term baby out of the body during childbirth. This organ is a complex and interesting reproduction structure of women anatomy. Despite its small size, this prominent organ takes big responsibility toward the continuation of human species. Its existence in Black women's body draws special attention and consideration from those the dominant in slavery era, especially the slave owners. They know well Black women's womb will make a huge benefit supporting their economy and political situation. With power and high position in society, the dominant has more opportunity to control the womb and function it as tool to reach their goals. This regime could easily eliminate Black women's right on their own reproduction system.

This phenomenon portrays a control toward Black enslaved women's body and justification to the interference of Black women's reproduction system. This controlling womb as well legitimates the exploitation of Black women's body to support capitalism in United Stated especially in the South. There are efforts the slave owners practiced in encouraging Black enslaved women to childbearing.

Collins (2000: 4) proposes three independent dimensions of the AfricanAmerican women's oppression; (1) economical oppression through exploitation and inclusion of Black women's bodies in system of capitalism in United States, (2) political oppression which denied African-American women the rights and privileges routinely extended to White male citizens; forbidding Black women to vote, excluding them from public office, and withholding equitable treatment in the criminal justice system all substantiate the political subordination of Black women, (2) ideological 


\section{Jurnal Poetika Vol. IV No. 1, Juli 2016}

oppression through controlling images applied to Black women that originated during slave era. Among these three dimensions, ideological oppression would be very helpful to discuss the issue of controlling womb in Morrison's Beloved.

Ideology (Collins, 2000: 5) refers the body of ideas reflecting the interests of a group of people. Within U.S culture, racist and sexist ideologies permeate the social structure to such a degree that they become hegemonic, namely, seen as natural, normal and inevitable. In this context, certain assumed qualities that are attached to Black women are used to justify oppression.

Collins (2000: 72) believes that the given ideas toward Black women's body works as controlling body. There are four negative images applied to African-American women in slavery era: (1) mammy, (2) matriarch, (3) breeder woman and welfare mother, (4) jezebel (Collins: 2000: 72: 81). Each image functions as regulation, control, and construction to Black women's bodies. However, among these four images, I would focus on the image of mammy, breeder woman and jezebel to reveal the ideological strategy of controlling Black enslaved women's womb in slavery era as well as nowadays. Collins (2000: 5) believes that these three images have become a negative stereotype applied to African-American women and it has been a fundamental to Black women's oppression.

The mammy image is central to intersecting oppressions of race, gender, sexuality, and class. Regarding racial oppression, controlling images like the mammy aim to influence Black maternal behavior (Collins, 2000: 73). This negative stereotype would be inherited to their children through maternal behavior in social relation especially in capitalism. Moms are hoped to be effective channel maintaining racial oppression as well as gender and sexuality by teaching their kids their social position (Collins, 2000: 74).

According to Christian (1980: 12-13) the image of mammy represents physical shape the black enslaved women owned with their strong huge breast. This physical appearance suits to the image of mammy allowing Black women to work as hard as men do. Their figure also refers to their ability in reproduction, with wide bottom and strong breast, the image of breeder woman is then come into surface.

The image of breeder woman allows exploitation of Black enslaved women's system of reproduction; sexually abused based on the potential fertility they possess. Collins (2000: 78) argued that the image of breeder woman provides an ideological justification for efforts to harness Black women's fertility to the needs of a changing political economy. During slavery, breeder woman portrayed Black women as more suitable for having children than White women. By claiming that Black women were able to produce children as easily as animals, this image provided justification for interference in enslaved African's reproductive lives.

King (1973: 12) states that slave owners wanted enslaved Africans to 'breed' because every slave child born represented a valuable unit of property, another unit of labor, and, if female, the prospects for more slaves. Moreover, the controlling image of the breeder woman served to justify slave owners' intrusion into Black women's decision about fertility. Meanwhile Collins (2004: 56) said that the image of breeder women represent Black women's bodies as the sites of wild, unrestrained sexuality that could be tamed but never completely subdued. This image emerged to defend the reproductive policies of slavery that encouraged enslaved Black women to have many children. Sexuality and fertility were neither designed for Black women's pleasure nor subject to their control. The dominant control their sexuality as well as fertility.

This leads to the construction of image jezebel which relegates all Black women to the category of sexually aggressive women (Collins, 2000: 81). The demand of excessive childbearing without legal marriage eventually put the Black women to the realm of prostitution. According to Caroline M. West (2012: 294) the image of jezebel originated from the vulnerable sexual violence the Black enslaved women experienced in the slavery era. The women with good reproduction 
capacity are much more desirable than those the barren one to sell. They are seduced, forced and instructed to have sexual relationship with their masters, sons, and male workers. Proposing themselves as the victim of rape is refused since this image identifies the Black women as the aggressive sexual creature themselves.

After all the ideological strategies the dominant established, to resist, Black woman are supposed to build self-definition as process of self-consciousness. Why self-consciousness and self-definition? Black intellectuals believe that the terms are fundamental for Black women rejecting the negative images attached to their bodies. Collins (2000: 112-121) proposes several keywords addressed to the selfdefinition which is prominent in assisting black women conducting resistance toward all kinds of oppressions, especially the ideological one. There are three elements of self-definition, (1) self-valuation and respect, (2) self-reliance and independence, (3) self, change, and personal empowerment. Having these three elements, Black women as well as its generation could decide what kind of practice they can do as a resistance toward all negative images attached on their black bodies. They supposed to begin knowing that their body is not anymore neutral but constructed in certain way during slavery era.

I found that issue of controlling womb is flourished in this work and is necessary to discuss further. Focusing on controlling womb, I would like to use Patricia Hill Collins ideological oppression theory to uncover how the Black enslaved women's wombs are objectified and how these women react through the action of resistance. This ideological oppression creates some negative images - as been explained above - underpinning Black women's bodies and is assumed to remain working on Black woman's bodies nowadays. Thus, based on the explanation above, this study aims to find out how Black enslaved women's womb is controlled through negative images and how the Black women react to the control of their wombs.

\section{Discussion: Mammy, Breeder Women and Jezebel for Womb Control}

To be a slave woman means to be a mammy, a breeder woman as well as jezebel, which are intertwined to each other. Mammy refers to slave women working as loyal maid -doing house chores, becoming good companion to the White master, and obeying every rules created in the house. Good mammy supposed to be a good breeder woman as well; she has to bear as much children as she can. It must be one among several requirements to be a good mammy. A good mammy is much more favored in the marketplace thus they could survive living even though under control of their masters. The image of breeder woman leads and is led by the image of jezebel, which assumes Black women as an excessive sexual appetite creature.

Through Denver, Morrison arguing the way the masters defined Black women's body during enslavement: "Slaves not supposed to have pleasurable feelings on their own; their bodies not supposed to be like that. But they have to have as many children as they can to please whoever owned them. Still, they were not supposed to have pleasure deep down..." (Morrison, 1987: 209) Slaves are just properties to their master, especially women whose body values more than those the Black men. Their womb could be used as reproduction machine to encourage the power of employment.

The development of capitalism in United States energizes masters to increase their property as well as their wealth, thus slavery was prominent to preserve especially in the South. Concomitant with that condition is the widely spread ideology toward black women's body; the mammy and breeder woman. This kind of ideology is rapidly growing in American society especially those related directly to the slavery. Collins (2000: 72) states that those constructed controlling images of Black womanhood reflect the dominant group's interest in maintaining Black women's subordination. Those controlling images are then important to the slavery's continuation function to mask social relations that affected all women. Black women are then excluded from the ideal character of women: 


\section{Jurnal Poetika Vol. IV No. 1, Juli 2016}

purity, piety, submissiveness, and domesticity. This characters suit only to the White woman, not the Black since negative images attached to the Black's bodies demand them to loss their purity, piety, submissiveness except domesticity.

With huge body figure, strong breast, and wide bottom, Black women are assumed a good breeder compared to the Whites. With this kind of physical appearance, Sethe is a potential asset for her master: Halle's girl... the one with iron eyes and backbone to match [9], Baby Suggs as well. Strong physical appearance legitimates the masters to exploit Black women's womb. Birthing children each year is normal to the Black women, ignoring the pain they might have. Masters believe on the Black body's maintenance if compared to the White women, they could be productive bearing children until 34 years old (Collins, 2000: 51).

Baby Suggs admits the risk of becoming a slave which takes away everything on the body. Whatever makes a benefit are overpowered by the other party, especially the masters. “... because slave life had "busted her legs, back, head, eyes, hands, kidneys, womb and tongue -wbich she put to work at once (Morrison, 1987: 87). The exploitation of the body allows every part of the body to be totally functioned; legs, hands, and back are to support working in the plantation or doing house chores, wombs are then prominent to bear many children each year. Such practice constructs also is constructed by the existed images -mammy, breeder woman and jezebel - in society especially the masters and the slaves itself.

Collins (2004: 56) argues that the image of breeder woman emerged to defend the reproductive policies of slavery that encouraged enslaved Black women to have many children. Sexuality and fertility are neither designed for Black women's own pleasure nor subject to their control. The system is designed to stamp out agency and annex Black women's bodies to as system of profit.

In time Sethe is arrested from her first effort escaping from Sweet Home things, Paul $\mathrm{D}$ insists that she will not be cut for punishment.
He believes that their masters will never do since Sethe possesses every asset the master need even compared to his own body. Sethe's body price is very expensive with that womb in hers and a baby in it. "Who in hell or on this earth would have thought that she would cut anyway? They must have believed, what with her belly and her back, that she wasn't going anywhere. He wasn't surprised to learn that they had tracked her down in Cincinniti, because, when he thought about it now, her price was greater than his; property that reproduced itself without cost." (Morrison, 1987: 228)

The newly born Black babies would automatically inherit their parents' status as slave - this is assumed to be a biological strategy to maintain racial discrimination. In other words the new generation of African American is still treated with the issue of racial segregation. The 'slave label' attached to the children works automatically as a system of profit. Masters do not need to spend more money buying new slaves; functioning Black enslaved women's bodies is enough to increase their capital and to cut the expense for employment procurement.

The practice is based on the capitalism principles, exploiting others to gain wealth and power. Bayart in Thomas (2003: 3-4) called womb exploitation engaged by the dominant as politic of belly-in which womb is the metaphor for belly. This means the womb is controlled under policies for the sake of dominant's importance. This politic of belly is used to be a theory finding facts about African history, however the principles is similar to what happens in the slavery era. The existence of womb gives significant contribution to the history of African as well as slavery in which elites insist on regulating African women's reproduction to support their political and power interest. Number of children is determined by the dominant eliminating women's right on their own bodies. The same thing with the image of breeder women legitimating ideological oppression toward Black enslaved women's womb.

Baby Suggs has eight children with six different fathers without legal marriage status; while Sethe has four children from a husband 


\section{Jurnal Poetika Vol. IV No. 1, Juli 2016}

with a marriage - a miracle Baby Suggs believed happens only to Sethe, an enslaved woman. Marriage is forbidden in enslavement, enslaved women are merely functioned to bear children even with different men each year. "Sethe had the amazing luck of six whole years of marriage to that 'somebody' son who had fathered every one of her children. A blessing she was reckless enough to take for granted, lean on....." (Morrison, 1987: 23-24)

An enslaved woman might deliver one kid every year up to ten or more kids, from biological relation to one man or more. Mostly born children were commoditized or kept as next young labor working in the plantation or houses. Once, Paul D met five women with their fourteen daughters. All men were taken away, killed or sold leaving the girls alive. "He had been in Rochester four years ago and seen five women arriving with fourteen female children. All their men-brothers, uncles, fathers, husbands, sons - had been picked off one by one." (Morrison, 1987: 52)

The women bearing children every year without legal marriage constructs as well as is constructed by the image of jezebel. Every Black woman is assumed to have excessive sexual appetite functions as justification to the control of Black women's womb. The dominant defines Black women as animal, which can produce as much children as they can to provide benefit the masters demand. "No, No. That's not the way. I told you to put her human characteristics on the left; her animal ones on the right. And don't forget to line them up." (Morrison, 1987: 193)

Being accustomed to the image of jezebel, the lives of Black women after slavery remain awful. They are sexually harassed both by the men of Black community as well as White. Sethe has to live alone soon after her escaping from the Sweet Home, taking care of the only girl left, Denver. Soon after Paul D's arrival, sexual activities are flourished between Sethe and him (Morrison, 1987: 20, 22). This happens because of the lack of Black women's awareness on their body's pride as well as Black men's lack of consideration toward Black women's value. Collins cites what Philip Bruce said (2004: 66) that the rape of a negress by the male of her own color is almost unheard of because the Black male is so accustomed to the wantonness of the women of his own race that it is not strange that his intellect, having no perception of the personal dignity of the pangs of outraged feeling, should be unable to gauge the terrible character of this offense against the integrity of virtuous womanhood.

To relate the jezebel with womb control, the excessive sexual appetites the Black women assumed to possess has been functioned to increase the exertion of Black women's fertility for the dominant's own sake. This is another way of ideological strategy maintaining the dominant position in the social hierarchical structure; Black women remain positing unfortunate position in the social structure.

With the potential womb in the body, enslaved women are much more favored, masters prefer to keep them as their belonging and leave them alive compared to the enslaved Black man. Enslaved Black women can work as enslaved Black men do, both have similar workload. This shows how bad masters exploit black women under slavery. Collins (2000: 51) cites Deborah Gray statement that slave masters wanted adolescent girls to have children, and to this end they practice passive, through insidious, kind of breeding. Techniques such as assigning pregnant women lighter work-loads, giving pregnant women with bonuses were all used to increase Black women's reproduction. Social punitive measures were also used. Infertile women could expect to be treated like 'barren sows' and be passed from one unsuspecting buyer to the next. Negative images always a good strategy used in the racial discrimination, including 'barren sows' refers to women unable to breed.

Mr. Garner has different strategy in encouraging his black women slaves to breed children, one among two strategies discussed here is permitting marriage happens between Halle and Sethe. She was 13 when she enters Sweet House to replace Baby Suggs working as a mammy. Becoming the only woman in the house, after Mrs. Garner, makes all Black 


\section{Jurnal Poetika Vol. IV No. 1, Juli 2016}

enslaved men in the house dreaming a sexual relationship with her. Mr. Garner, however, forbids them to bother her and let her grows until she is ready for breeding. He gives her one year to think and choose which man she wants to marry with. "She waited a year. And the Sweet Home men abused cows while they waited with her. She chose Halle and for their first bedding she sewed herself a dress on the sly" (Morrison, 1987: 11).

At time Sethe discussed her planning to get married with Halle, Mrs. Garner agreed right away. "Halle and me want to be married, Mrs. Garner/ So I heard... He talked to Mr. Garner about it. Are you already expecting?/ No, Ma'am/ Halle's nice, Sethe. He'll be good to you." (Morrison, 1987: 26) This is not because of they are nice but they understand marriage will let Sethe and Halle having a biological relation to bear as much children as she can. Those children are then claimed to be their property or belonging; a capital to support their capitalism business.

Another strategy addressing to the interest of breeding children conducted by $\mathrm{Mr}$. Garner is creating impossible debt to pay. By letting Halle to buy Baby Suggs' freedom, Mr. Garner has the access to control their bodies -Halle's, Sethe's and their children. Needless to say, this kind of strategy is not necessary to do since the image of breeder women has already attached to Sethe's body legitimating the action of breeding children each year.

Halle promises himself, Sethe and their children to pay off all the debt he has since he frees his mother, Baby Suggs. He feels that Baby Suggs condition is no longer proper for hardworking in Sweet Home and she should make change over her life after freedom. Garner as well knows that she is no longer beneficial, since she is old enough and her hips are broken, she could make harm towards all stuffs in the house when suddenly she falls down. Halle assures Sethe his reason to free Baby Suggs: "She worked here for ten years. If she worked another ten you think she would've made it out? I pay him for her last years and in return he got you, me and three more coming up. I got one more year of debt work; one more. Schoolteacher in there told me to quit it. Said the reason for doing it don't hold. I should do the extra but here at Sweet Home."(Morrison, 1987: 196)

After all Garner owned Sethe's body as well as her children, totally. Halle is no longer able to pay even with his extra working, it could never pay off the debt he has. "If my labor is Sweet Home, including the extra, what I got left to sell:" (Morrison, 1987: 196)

Low economic condition suffered by slaves is in purpose created in order that the dominant has discretion in controlling their marginal position. The existence of negative images works well in positing Black women as the Other, even after the era of slavery. Women's negative image as mammy, breeder women and jezebel place them in a less favorable position among society. Even today, these images remain working and give influence in the lives of ex-enslaved women and their generation. Mammy provides them with low-waged job with bad and dirty working environment; breeder women become a serious consideration to the new policy controlling Black women's womb nowadays, meanwhile the image of jezebel let them facing continuously sexual violence in society.

A new form of womb control is then practiced, not anymore forcing Black women to breed as much as they can rather a limitation of birthing Black babies. Black women's low economic condition becomes a justification to this limitation; the dominant needs to restrict the Black babies since - according to them - it will harm the social and politic condition of the country. Given the poor economic condition, Black babies will grow in poor families and increase the number of unemployment whenever they are grown up.

The low economic condition the Black women experience after slavery has strong connection to the preserved images built during the slavery era. Ross et.al (2010:4) stated that during the slavery era the Black women are forced to bear as many children as they can for the sake of capitalism, now Black women must stop birthing because of their economic condition. Further she says that (Ross et.al; 


\section{Jurnal Poetika Vol. IV No. 1, Juli 2016}

2010:5) the shortage of reproduction health knowledge and services increase the rate of mortality among Black women and kids. Collins (2000: 54) called this situation as a new shape of new racism. Without sufficient knowledge and access to the reproduction health service, many Black women decided to do risky abortion.

Coercive sterilization toward Black women's womb are also practiced through several programs such as Planned Parenthood (1916), the Negro Project, Cesar Operation which are indirectly taking away Black women's right on their own reproduction. Hundred thousands of abortion has been experienced by the Black women and some of them are sterilized (K. Abel, 2014). The interference of the outer institution toward the Black women's womb shows that racial, classism, and gender issue are still the ground of all discrimination and oppression toward Black women's body, particularly the wombs.

Morrison tries to reveal this through her novel that what happens in the past need to be reconsidered. There are many unspoken stories about personal lives the Black women experience during the slavery era which has connection to nowadays condition. She ensures the readers that the discrimination is still varied there and it started from hundred years ago through the ideological oppressions in form of negative images such as mammy, breeder woman, and jezebel. These images are still working until now.

\section{Self-Definition to Deny the Image of Mammy, Breeder Woman, and Jezebel}

Morrison represents Baby Suggs and Sethe as the agent finding self-identity within geographic and space limitation. Clearing is chosen by Baby Suggs to empower herself in a wider community -more than herself as an individual, meanwhile Sethe decides to react physically the injustice she has to deal with. Clearing is a space for Black community gather and share their feeling also heal trauma of the past. Baby Suggs assures herself that even though the hands, legs, heads, dreams, and wombs has been busted through slavery, there is a heart remaining. She believes that Black women have to start respecting their own body and love themselves. "....because slave life had "busted her legs, back, head, eyes, hands, kidneys, womb and tongue," she had nothing left to make a living with but her heart-which she put to work at once. Accepting no title of honor before her name, but allowing a small caress after it, she became an un-churched preacher, one who visited pulpits and opened her great heart to those who could use it." (Morrison, 1987: 87)

Through the Clearing, Baby Suggs establishes an interpersonal relationship among the ex-slaves and builds new self-power both as individual as well as part of community. Lorde (1984: 40) believes that personal relation created in a community is beneficial for Black women to create identity substituting certain geographical area. Baby Suggs helps the people in the community to express their sadness, fear, anger, disappointment, and hopes through tears, weeps, dances and songs sang in the Clearing. This is done not to regret the condition these Black community face, yet to build a way of freedom expressing themselves. She motivates the people to love the body even the Whites teach them not to love the bodies (Morrison, 1987: 87).

Self here could not be defined as being autonomy isolating self from the wide community rather found in the context of family and community. Baby Suggs ensures the people to create their own gift since the gift is not provided by the Whites or the world. According to Tate (1983: 134) the action Baby Suggs conducted here is a form of responsibility toward others, which will eventually help Black women to grow as a whole un-objectified individual.

Baby Suggs defines herself through her involvement and interrelation to the environment, she had better do that rather than to directly fight against her opposition physically. Her action could give a more deep meaning for Black women's self-definition. Starting from her own, she invites other people to create strong connection with others through 


\section{Jurnal Poetika Vol. IV No. 1, Juli 2016}

the Clearing. Acknowledging the existence of their community, thus they are as well realizing their self-definition.

Self-definition is convinced to be the first step ruining the existed and inherited definition the dominant gives through images such as mammy, breeder woman and jezebel. Through her preaching in Clearing (Morrison, 1987: 88) she indirectly tries to release the people from the image attached to their bodies, which regulates the wombs. She understands that there is control over the body particularly the womb. She knows that the Whites will never accept their skin color and treat the Black equal to them. The Whites seem rejecting the existence of Black as a whole human, but objectified them as things. Their subjectivity is dismissed and refused. In Clearing Baby Suggs introduces the people the importance of self-definition, she invites them to accept and love their own body: the hands, legs, eyes, mouths, wombs and hearts. By loving the bodies, respect toward the bodies will eventually be created.

Collins (2000: 113) states that the journey toward self-definition has political significance and function as an action of resistance toward the bad images preserved. Black women should stop accepting those negative images and tries to realize their own reality and reconstruct their own definition. With this self-definition, the existed images attached to the bodies are then revised or recreated for a new identity. This identity is not the goal at all anyway, yet a beginning step in the process of self-definition. They will find facts that their lives have been fundamentally constructed in the intersection of race, gender, sexuality and class.

Not only to the community, have Baby Suggs as well taught Denver to start finding her own self-definition. In Denver's crucial time, she is able to find her own choice from the silence toward the spoken. She empowers herself to save her mother's lives, which has been corrupted by Beloved, and start a new job for living. Denver can escape from the dark side of her past live and build new future by employing herself. I want work, Miss Lady..... I can't do anything, but I would learn it for you if you have a little extra." (Morrison, 1987: 248)

Different way managed by Sethe to react the injustice the dominant conducts to control her womb. She decides to escape from Sweet Home in order to release herself from being excessively used as children production machine. Her runaway constitutes her efforts to reject negative images attached to her body as mammy, breeder woman, as well as jezebel. Without the images on her body, she starts to (1) reject her womb from being exploited, (2) have her own choice to decide whether she wants to have children or not, and other (3) create strong relation with her children. That's when we should have begun to plan... I don't know what we thought but getting away was a money thing to us" (Morrison, 1987: 197).

Getting away is the only thing Sethe can do for her own sake as well as children. She doesn't want her children to inherit her status as slave. Running away, according to Sethe, is also the only choice to remove stereotypes regulating her body. Indirectly Sethe has realized that there is dominant ideology taking control over her womanhood aspects; in form of mockery and detraction.

The running away is regarded as a respectenergized action, not yet a self-conception though, but this is a brilliant start Sethe could perform for her self-definition. Managed differently, the action is similarly grounded to what Baby Suggs does in Clearing; Sethe starts to love her body which has been hated and rejected by the Whites.

Meanwhile, Black women sexuality which is regarded as excessive and aggressive thing has been denied both by Baby Suggs and Sethe. The feeling of nastiness is enough to show that these Black women have different idea toward their own sexual character; it proves that the idea about their sexual characteristic the dominant assumed is wrong. Baby Suggs (Morrison, 1987: 23) felts sorry for the condition asking her doing sexual activities with many of men -which is regulated by the masters; meanwhile Sethe keeps herself away 


\section{Jurnal Poetika Vol. IV No. 1, Juli 2016}

from sexual intercourse after being separated from Halle until Paul D came and decides to live with him. "She wanted Paul D. No matter what he told and knew, she wanted him in her life... the weight and angle of him; the true-to-life beard hair on bim; arched back, educated hands. His waiting eyes and awful buman power." (Morrison, 1987: 99) Sethe has her own consideration to live with Paul D, and she is the one to decide about her own life without anyone interfering.

Both women have their own way escaping from the images attached to their body but similar in the ground i.e. building self-definition to react the ideological strategies the dominant performs. To face new form of womb control nowadays, however, Black intellectual women gain power through reproduction movementand abortion movement asking for Black women's reproduction right. This action is automatically animated by their self-consciousness and the ability executing their self-definition. Even once the abortion movement is controversial as it is assumed rebuilding the dark memory of Black women in the slavery era, but Ross (2011: 13) believes it will help Black women controlling their own body, biological system and reproduction. It also liberates them from the unwanted pregnancy and eventually turns to a fundamental politic of the body. Sherman (2014) agrees with Ross that the abortion movement constitutes a resistance toward the system of patriarchy, Whites' supremacy and the system of oppressions; meanwhile the coercive program of sterilization to the Black women's womb has been rejected through Black women movement in 1960s (Krase: 2014).

Black intellectual writings are also manifestation of self-definition the Black women have; Toni Morrison's Beloved, for instance. Morrison's writing occupies what Collins (2000: 94-96) proposes about the characteristics of Black writings (1) escaping from a world predicated upon derogated images of Black womanhood, (2) Black women's denial to the controlling images of Black womanhood, and (3) not only portraying the range of responses that individual African-American women express concerning their objectification as the other; they also document the process of personal growth toward positive self-definition. Thus, through the representation of Sethe, Baby Suggs and Denver; Morrison reacts to the gender, race, and sexist segregation experienced by Black women.

\section{Conclusion}

To conclude, there is ideological oppression in form of controlling images applied to the body of Black enslaved women in Beloved. With the image of mammy, breeder woman and jezebel, Sethe and Baby Suggs's wombs are controlled by their masters or the dominant. The image of mammy takes Sethe and Baby Suggs to works restlessly; it demands them to be a breeder woman as well by birthing children every year to suffice their master's slave's number. Being assumed as sexually aggressive creature, Sethe and Baby Suggs' fertility is used excessively to provide babies for their master's profit. Without legal marriage, they turn to be a jezebel. The images, unfortunately, remain there among the modern society positing Black women in a more severe situation, even after slavery is ended. The historical background the Black women have in slavery era together with the images constructed lead the Black women nowadays to unfortunate position in social hierarchical structure. The low economic condition generated by the image of mammy provides the Black women domestic space to stay and low wages for living. Assumption on their excessive sexual appetites judges them unable stopping the birthing children under poor financial support. Thus, new form of womb control toward poor young generation of Black women is performed nowadays. Limitation of birthing Black babies is conducted through several strategies, such as lack of reproduction health service, lack access of contraception, and programs of coercive sterilization.

However, Morrison depicts reaction the Black women perform to fight against the ideological oppression. Self-definition is 
believed to be fundamental way out the Black women should manage to refuse negative images attached to their bodies. Through the ability of realizing self-reality, Sethe, Baby Suggs and Denver start to construct their self-definition. This self-definition increases respect to the body which lead to the action of resistance to release the bodies from control. Baby Suggs choses Clearing to support her transformation of self-definition, Sethe escapes from Sweet Home to free her body from birthing children, and Denver starts to empower herself as a professional employer in public space. The reproduction movement and abortion movement as well as refusing to the coercive sterilization appears to be another way to resist the new strategy of womb control.

To end this essay, I believe that the issue of womb control in literary works is still rare and can be explored more using another theory to get another point of view.

\section{Reference}

Collins, Patricia Hills.2000.Black Feminist Thought: Knowledge, Consciousness, and the Politics of Empowerment. New York and London: Routledge

- 2004. Black Sexual Politics: African Americans, Gender, and the New Racism. New York and London: Routledge

Christian, Barbara. 1980. Black Women Novelists: The Development of a Tradition. Connecticut.

King, Mae. 1973. "The Politics of Sexual Stereotypes." Black Scholar

Lorde, Audre. 1984. Sister Outsider. Trumansberg. New York: Crossing Press.

Morrison, Toni. 1987. Beloved. New York: Random House

Omolode, Barbara. 1994. The Rising Song of African American Women. New York: Routledge.

Ross, Loretta J, et.al. 2010. Race, Gender and Abortion: How Reproductive Justice Activists Won in Georgia. SisterSong Policy Report. Atlanta
Tate, Claudia, ed. 1983. Black Women Writers at Work. New York: Continuum Publishing.

Thomas, Lynn M. 2003. Politics of the Womb: Women, Reproduction, and the State in Kenya. University of California Press.

West, C. 2012. Mammy, Jezebel, Sapphire, and Their Homegirls: Developing an "Oppositional Gaze" Toward the Images of Black Woman. Washington: University of Washington.

\section{Websites:}

Abel. K. 2014. 5 Examples of the War on the Black Woman's Womb. Retrieved from www. atlantablakcstar.com. 31 December 2015.

Tim Taylor, 2016. Anatomy and Physiology Instructor. Retrieved from http://www. innerbody.com/image_repfov/repo11new.html\#full-description. 6 June 2016

Krase, Kathryn. 2014. History of Forced Sterilization and Current U.S Abuses. Our Bodies Selves Information Insipres Action. Diunduh dari http://www. ourbodiesourselves.org/health-info/ forced-sterilization. 22 February 2016. 